\title{
Out of Many, One: European film-makers construct the United States
}

Melvyn Stokes and Dominique Sipière

\section{(2) OpenEdition \\ Journals}

Electronic version

URL: https://journals.openedition.org/ejas/8650

DOI: $10.4000 /$ ejas.8650

ISSN: 1991-9336

Publisher

European Association for American Studies

\section{Electronic reference}

Melvyn Stokes and Dominique Sipière, "Out of Many, One: European film-makers construct the United States", European journal of American studies [Online], 5-4 | 2010, document 1, Online since 12

November 2010, connection on 08 July 2021. URL: http://journals.openedition.org/ejas/8650 ; DOI: https://doi.org/10.4000/ejas.8650

This text was automatically generated on 8 July 2021.

Creative Commons License 


\title{
Out of Many, One: European film- makers construct the United States
}

\author{
Melvyn Stokes and Dominique Sipière
}

1 The Latin phrase e pluribus unum (out of many, one) was the motto proposed by John Adams, Benjamin Franklin and Thomas Jefferson for the first Seal of the United States in 1776. It would later be included on most American currency and in the Seal of the President of the United States. Originally intended to suggest that out of the thirteen independent states declaring their independence from Britain would emerge a single country, it would later imply that the United States was attempting to create a unified nation from people with many different backgrounds and beliefs. Both formulations were far from unanimously accepted. There was strong opposition to the Federal Constitution of 1787. New England Federalists toyed with the notion of leaving the United States during the War of 1812. South Carolina flirted with a kind of secession during the nullification crisis over the tariff in 1832. Garrisonian abolitionists of the 1840 s favoured the idea of seceding from the slave power. Southern slave states threatened to secede from the Union before the Compromise of 1850 was adopted and eleven Southern states actually did so in 1860-61 to form the Confederate States of America. Although the Union's victory in the Civil War settled for good the issue of whether the United States would remain a single country in political terms, embers of the South's resistance to Federal power remained during the civil rights movement and in the lingering controversy over the flying of the Confederate flag over monuments and state buildings in some states.

2 Building one nation from a diverse range of ethnicities would also prove problematic. Some racial groups, particularly Native Americans and African Americans, for much of American history were regarded as inassimilable into a (predominantly white) society. Other groups (such as the Chinese in 1882) were banned from further immigration into the United States. At other times - as in the late 1790s or with the Know-Nothing movement of the 1840s and 50s or the demands for restricting immigration in the late nineteenth and early twentieth centuries - the perception of the United States as a country that welcomed foreigners into the country, confident that they would be 
assimilated through the "Melting Pot" of American society, became perceptibly weaker. Such insecurity was sometimes accompanied by official and semi-official pressure - as during the First World War - to "Americanise" immigrants as thoroughly as possible. The other side of the coin, however, was the recognition that, far from weakening and disappearing into a composite "American" identity, there were some periods of American history in which ethnic ties and loyalties actually became stronger ${ }^{11}$ This, in recent times, has led to a growing recognition of the United States as a pluralist society.

3 Nations themselves, as Benedict Anderson pointed out, are "imagined communities." They are brought together by a common sense of shared identity and values, together with a perception that - transcending all groups, regions and classes - there is a sense of social cohesion. Anderson himself noted that "regardless of the actual inequality and exploitation that may prevail in each, the nation is always conceived as a deep, horizontal comradeship". ${ }^{2}$ This view of fraternity - and consequently the view of nationhood that accompanied it - was born, Anderson argued, from a combination of economic and cultural innovation: the birth of print capitalism, using a vernacular language, which made it possible for readers with different local and regional dialects to understand one another. By reading newspapers, they identified themselves as members of the same nation.

4 In the long run, the impact of print media in forging ties of nationhood was greatly supplemented by the rise of cinema - the dominant mass-media of the first half of the twentieth century and still influential in the second half of the century. By the end of the First World War, the American film industry dominated not only the domestic market in the United States but also the movie marketplace throughout much of the world. It presented images of American society and nationhood not only to Americans themselves, but also to countless millions of foreigners who were frequently entranced by the skill and professionalism of American films. Hollywood became the great "dream factory" and one of the most seductive dreams it spun was the dream of a particularly American form of national community. In his study of the influence of Jewish immigrants on Hollywood, Neal Gabler argued that these men - ethnic outsiders themselves - created on screen a uniform and fictionalized America of small towns and strong communities, in which the middle class predominated, and that this view of what it meant to be "American" came to define America for Americans as well as for the rest of the world. ${ }^{3}$ By contrast, in The Big Tomorrow, Lary May contended that the traditional values and ideology associated with the Hollywood studio system were far from being as monolithic as had often been assumed: films until the Second World War often recognized racial and social differences, but this was reversed by the conservative, anti-communist backlash after $1945 .^{4}$

5 The articles in this issue of the EJAS are intended to shed light on how European filmmakers have constructed their own "America" - a nation that is socially and culturally cohesive (pluribus unum) or composed of many different social and ethnic elements (pluribus plura). Since the very beginnings of cinema, Europeans have been involved in interpreting and commenting on "America" on screen both to American and foreign audiences. Many European directors have made films with American subjects (a very partial list would include Michelangelo Antonioni, Constantin Costa-Gravas, Frank Darabont, André de Toth, Julien Duvivier, Roland Emmerich, Milos Forman, Emir Kusturica, Sergio Leone, Anatole Litvak, Ken Loach, Adrian Lyne, Wolfgang Peterson, Jean Renoir, Jacques Tourneur, Paul Verhoeven, and Wim Wenders). Equally, many 
directors of European origin were assimilated into "Hollywood" - illustrations of this would include Richard Boleslavsky, Frank Capra, Michael Curtiz, William Dieterle, Alfred Hitchcock, Fritz Lang, Ernest Lubitsch, Rouben Mamoulian, Friedrich Murnau, Otto Preminger, Douglas Sirk, Charles Vidor, Josef von Sternberg, Erich von Stroheim, James Whale, Billy Wilder, William Wyler, and Fred Zinnemann. Frequently, in projecting their own view of a unified or diversified American society and nation, such directors were greatly influenced by their own personal and national experiences.

6 Each of the contributors to this issue has developed his or her own approach to the overriding theme. Ian Scott notes that much of the commentary dealing with British émigrés in Hollywood in the first part of the twentieth century has focused on actors beginning to arrive from the late 1920s onwards - men such as George Arliss and C. Aubrey Smith - who created in their films a certain construction of "Britishness" that had its roots in the conservatism of the past. In reality, Scott points out, an earlier generation of British writer-directors (Charles Brabin, Colin Campbell, Reginald Barker and Frank Lloyd) not only avoided being stereotyped as "British" but - helped by their transnational perspective - were more open to the nuances of American history and the American experience than many US film-makers. In particular, in westerns, Barker foregrounded the complexity of the relationship between Native Americans and western pioneers, together with the ambitions of railroad corporations. Hilaria Loyo looks at the involvement in a later western - Rancho Notorious (1952) - of two German émigrés: director Fritz Lang and actress Marlene Dietrich. In this, one of his more "personal" works, Lang contributed a foreign perspective to the indigenous genre of the western. Beginning the film with the rape and murder of a young woman, followed by an obsessive quest for revenge by her fiancé, Lang questioned the masculine aggression characterizing the traditional western. By making Altar Keane (Dietrich) the boss of the Chuck-a-Luck ranch, an outlaw haven, he also undercut the emerging conservative gender ideology of the Cold War - men worked and women stayed at home. Finally, by manipulating Dietrich's star persona - particularly her association with modernization and consumer culture - his film exposed cultural and social conflicts in the contemporary US, including the fragility of female empowerment based on consumption.

7 While Scott and Loyo explore how European film-makers approached American issues and themes, Yves Carlet traces the strategies used by two "American" directors born in Europe - Frank Capra and Elia Kazan - to try to force their way into the dominant "Anglo" culture. Examining their autobiographies, together with their films and works written about them, Carlet concludes that Capra and Kazan - despite in each case rejecting part of their family heritage - always remained to some extent social and cultural outsiders. There was, he finds, a "kind of covert dialogue" between their autobiographies, as well as a number of parallels between their films. Yet on the pluribus unum/pluribus plura debate, they differed crucially. Capra, who evinced little interest in his own roots and did not even visit Sicily until he was nearly 80, also tended to ignore ethnicity in his films: the American society he portrayed was largely Anglo, small-town and middle-class. Social divisions were on economic, not ethnic lines: Capra's dislike of "big fat businessmen" was expressed in several of his films. Kazan, by contrast, addressed ethnicity in films such as Gentleman's Agreement (1947) and Pinky (1949). He also rediscovered his native land when he returned to Greece and Turkey to shoot America, America (1963) and thought of returning to live there in his later years. 
8 In his article, Jeffrey L. Meikle explores the development of the road movie in the aftermath of Easy Rider (1969). He shows how, in the films of German Wim Wenders, Finn Aki Kaurismäki and American Jim Jarmusch (who displays "an aesthetic informed by European world-weariness"), the road movie developed from a typically "American" genre into an expression of transatlantic cultural hybridity. While directors such as Wenders grew up heavily conditioned by post-war American popular culture, they were not "colonized" in a simple sense: whether in Wenders's Alice in the City (1974) and Paris, Texas (1984) or Kaurismäki's Leningrad Cowboys Go America (1988), they presented a critical image of America foregrounding its marginalized characters, its stereotypical sameness and often its ruined environment. Jarmusch, inspired by the early films of Wenders (who gave him blank film stock to complete his second feature film), offered an equally jaundiced view of American society seen through the eyes of a collection of European drifters in films such as Stanger Than Paradise (1984), Down By Law (1986) and Mystery Train (1989). These Euro-American road movies emphasized the ambivalence and diminishing expectations of modern (or even post-modern) America.

9 The estrangement from American society demonstrated by Wenders, Kaurismäki and Jarmusch was paralleled in two films of the 1980s by Spanish directors: José Luis Borau's On the Line (1984) and Bigas Luna's Reborn (1981). Each dealt with a darker side of the Reagan era: Borau with the trafficking of Mexican immigrants, Bigas Luna's with the murky world of tele-evangelism. Vincente J. Benet sees the two films as revolving around issues of social hybridity and posing the question whether a unified, monolithic American culture built on conservative values can tolerate the existence of social groups with divergent cultural traditions. In this regard, he believes, they anticipate the current interest of social and cultural researchers in issues of transnationality, diaspora and exile. Borau and Bigas Luna approached making these films from a genuinely transnational perspective. On the Line, for example, begins as a border movie exploring the hybrid space between Mexico and the United States but ultimately evolves into a Hispanic melodrama. Reborn reflected Bigas Luna's personal reconciliation with the traditional church: it was intended to critique the commercialisation of religion. In both films, the central relationship is a hybrid one between an American male and a non-American female. In each case, the film ends on a note of ambiguity: have these relationships (and cultural hybridization itself) a future in conservative, Reaganite America?

10 Emir Kusturica's Arizona Dream (1993), argues David Roche, is a film informed by the Sarajevo-born director's lament for the loss of the multi-cultural, multi-ethnic society of the former Yugoslavia. It suggests that the United States has constructed itself as a nation by denying the reality of otherness while simultaneously using its financial power to feed on the other. Yet, while offering a political and cultural analysis of the US, the film also foregrounds the fact that the America it constructs is that offered by a European auteur. (One example of this is the dense network of citations from other movies, many of them by or featuring Europeans.) Arizona Dream focuses particularly on two areas - Alaska and Arizona - that were effectively bought by the United States. That these places had their own cultural traditions - in effect, their own dreams before becoming part of the United States, Roche contends, suggests a political reading of the US as a land bought by "real" Americans, that influences Kusturica's own treatment of ethnic diversity. The fact that the film was framed by its Inuit dreamsequence evokes the notion of race as a side or marginalized issue - something 
confirmed by various figures of otherness appearing in the film. These (particularly the Asian tailor and the Mexican band) are accepted for their economic function by Americans who deny their right to cultural difference. American national unity, Arizona Dream proposes, is itself ultimately a dream - but a dream that can be constructed by both Americans and non-Americans alike.

11 According to Frank Mehring, two films by German émigré directors - Roland Emmerich's Independence Day (1996) and Wim Wenders's Land of Plenty (2003) - offer a very different take on American patriotism. Emmerich's film is a science fiction blockbuster that not only accepts American founding myths, but generalises them for the rest of the world (a US President leads a campaign to destroy aggressive aliens - he is photographed addressing an ethnically diverse group of fellow-fighters). This benign view of America, Mehring notes, had its origins in the Marshall Plan and the positive example Hollywood heroes (including Marshall Will Kane in High Noon) provided for many young Germans after the war. It effectively denies any "democratic gap" between American political ideals and cultural practice. Emmerich's film, for American audiences, seemed to demonstrate "why they all love us." Wenders's film, released two years after 9/11 and aimed at the more limited (and more left-wing) art-house market, addresses the very different question: "why do they all hate us?" Unpopular with American critics, Land of Plenty is a protest by a German Americanophile whose dream of "America" has been hijacked by the Bush Administration into a spurious "war on terror." In the figure of Paul, the Vietnam vet who has metamorphosed into a selfappointed homeland security agent, Wenders exemplifies what de Tocqueville once described as "irritable patriotism." His film also foregrounds the flip side of the American democratic experiment: there are many shots of the poor and excluded in what, to Wenders and other European film-makers, had once seemed a highly inclusive "land of plenty."

12 The questions raised here in terms of the contribution made by European film-makers to the representation of the United States as either a unified or diverse and pluralistic nation are clearly very broad ones indeed. Consequently, this issue of the EJAS web journal and the articles it contains are envisaged as only the start of a wider discussion. The issue itself will remain "open" and further contributions will be welcomed. Anyone wishing to submit an article is asked to contact the two guest-editors.

\section{NOTES}

1. See, for example, Nathan Glazer and Daniel Patrick Moynihan, Beyond the Melting Pot: The Negroes, Puerto Ricans, Jews, Italians and Irish of New York City (Cambridge: Massachusetts Institute of Technology Press, 1963).

2. Benedict Anderson, Imagined Communities: Reflections on the Origins and Spread of Nationalism (London and New York: Verso, rev. ed., 1991, originally pub. in 1983), 7.

3. Neal Gabler, An Empire of Their Own: How the Jews Invented Hollywood (New York: Crown, 1989). 
4. Lary May, The Big Tomorrow: Hollywood and the Politics of the American Way (Chicago: University of Chicago Press, 2000).

\section{AUTHORS}

\section{MELVYN STOKES}

University College London, melvynstokes@hotmail.com

DOMINIQUE SIPIÈRE

University of Paris Ouest-Nanterre la Défense, sipiere@wanadoo.fr 